UDC 635.649-238

Original research paper

doi: 10.5937/AASer1846141M

Acta Agriculturae Serbica, Vol. XXIII, 46 (2018); 141-155

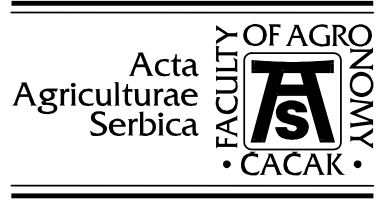

\title{
Occurrence and diversity of viruses infecting pepper in Serbia
}

\author{
Dragana Milošević ${ }^{1}$, Maja Ignjatov ${ }^{1}$, Ivana Stanković ${ }^{2}$, Zorica \\ Nikolić $^{1}$, Jelica Gvozdanović-Varga ${ }^{1}$, Branka Krstićc \\ ${ }^{1}$ Institute of Field and Vegetable Crops, Maksima Gorkog 30, 21000 Novi Sad \\ ${ }^{2}$ Institute of Phytomedicine, Department of Phytopathology, University of \\ Belgrade-Faculty of Agriculture, Nemanjina 6, 11080 Belgrade \\ Corresponding author: dragana.milosevic@nsseme.com
}

\begin{abstract}
A two-year investigation (2009-2010) of the presence and distribution of pepper (Capsicum annuum L.) viruses in Serbia revealed that viruses occur each year in open-field production. Disease incidence, as estimated by the number of symptomatic plants in the field, highly varied depending on the year and sampling locality. Disease incidence ranged from $20 \%$ to $60 \%$. Four viruses: Cucumber mosaic virus (CMV), Potato virus Y (PVY), Alfalfa mosaic virus (AMV) and Pepper mild mottle virus (PMMoV), of which PVY was predominant, were detected by serological testing of pepper samples collected from many localities in Serbia. Molecular detection of PVY was performed based on amplification of a 975 bp fragment in all tested samples, using the specific primers PVYc/PVYd that amplify the gene for P1 protein. The RT-PCR products derived from the four isolates (PL-28-09, PL-15-09, PL-3-10, PL-108-10) of PVY were sequenced (KC288142, KC288143, KC288144, and KC288144, respectively) and compared with the PVY sequences available in GenBank. Sequence analysis, conducted with MEGA5 software, revealed 99.8-100\% nt identity among the four Serbian PVY isolates from pepper. The sequences of PVY isolates from Serbia share the highest nucleotide and amino acid identity with isolates from Slovenia, Croatia, Germany, and tobbaco isolate from Serbia. All of the four Serbian isolates were clustered in sub-group N-1 with other European isolates of necrotic strains.
\end{abstract}

Keywords: pepper viruses; Potato virus Y; serological assay; RT-PCR; molecular characterization.

Received 9 May 2018 Accepted 5 June 2018 


\section{Introduction}

Pepper (Capsicum annuum L.) is among the most important vegetable crops in Serbia. It is the second most widely grown vegetable crop in Serbia, covering the area of about 20,000 ha of open-field and protected crops, with an average yield of $8.3 \mathrm{t} / \mathrm{ha}$. In Serbia, different types of pepper are grown for fresh consumption, processing and the production of spices. The main pepper production region, about $80 \%$ of the national production, is concentrated in the Vojvodina Province.

Viral diseases constitute the major limiting factor in pepper production, affecting both yield and quality of pepper fruits (Nono-Womdin, 2001). They caused economic losses of 15 billion dollars annually on worldwide basis (Van Fanbing 1999), particularly in tropical and semitropical regions, but great losses have also been reported in temperate regions (Hull and Davies, 1992). Sixtyeight viruses have been reported to cause damages in pepper crops (Pernezny et al., 2003), among which the most significant and widespread pepper viruses in the Mediterranean Basin are aphid-transmitted, Potato virus Y (PVY), Cucumber mosaic virus (CMV) and Alfalfa mosaic virus (AMV), the thrips-transmitted Tomato spotted wilt orthotospovirus (TSWV), as well as seed- or mechanically transmitted tobamoviruses, Pepper mild mottle virus (PMMoV), Tobacco mosaic virus (TMV), Tomato mosaic virus (ToMV), and Tobacco mild green mosaic virus (TMGMV) (Moury and Verdin, 2012).

Potato virus Y (PVY: genus, Potyvirus, family Potyviridae) is dispersed worldwide and it is one of the most common and destructive viruses infecting potato, tomato, tobacco and pepper. PVY strains have been classified into five groups: $\mathrm{PVY}^{\mathrm{O}}$ (ordinary strain), $\mathrm{PVY}^{\mathrm{C}}$ (common strain), $\mathrm{PVY}^{\mathrm{N}}$ (necrotic strain), $\mathrm{PVY}^{\mathrm{Z}}$ and $\mathrm{PVY}{ }^{\mathrm{E}}$ based on reaction in potato plant carrying resistance genes $\mathrm{Ny}$, $N c$, and $N z$, as well as tobacco symptoms (Chikh-Ali et al., 2013). In addition, new recombinant genotype/strains have been identified based on sequence analysis, including $\mathrm{PVY}^{\mathrm{NTN}}$ and $\mathrm{PVY}^{\mathrm{NWI}}$, which have mosaic genomes built of fragments of $\mathrm{PVY}^{\mathrm{N}}$ and $\mathrm{PVY} \mathrm{O}^{\mathrm{O}}$ sequences (Ali et al., 2010). $\mathrm{PVY}^{\mathrm{NTN}}$ and $\mathrm{PVY} \mathrm{NWI}^{\mathrm{NWI}}$ were first found in Hungary and Poland, respectively, but within a short period of time they have become common in potato fields (Ali et al., 2007). Of the 26 species of the family Aphididae, Myzus persicae is the most efficient PVY vector (Katis and Gibson, 1985; Woodford, 1992). The virus is not seed-borne (Jones et al., 2014).

Despite the importance of pepper in Serbia, only local and limited information is available about the presence and incidence of viruses (Mijatović et al., 2007; Krstić and Bulajić, 2008). In recent years, an extremely high percentage of early virus infections of pepper have caused severe plant stunting, and leaf and fruit malformation was observed in many pepper crops in the Vojvodina Province (Petrović et al., 2010). A two-year survey was conducted in order to give an insight into the occurrence and distribution of viruses infecting 
pepper crops in Serbia, by evaluating their relative incidence and potential importance using DAS-ELISA test. This study also focused on determining the presence of PVY using molecular testing and establishing the genetic relationship of its isolates originating from Serbia with those from other parts of the world.

\section{Materials and Methods}

\section{Sample collection}

During 2009 and 2010, from June to August, research was conducted to investigate the presence and distribution of pepper viruses in Serbia. A total of 365 samples were collected from open-field production. Samples comprising leaves from plants with symptoms resembling those of virus infection were randomly collected after the visual inspection of 31 different localities. Each sample was placed in a plastic bag and stored at $4^{\circ} \mathrm{C}$ until testing by ELISA or RT-PCR.

\section{Serological assay}

Serological testing was performed by double-antibody sandwich (DASELISA) kits using antisera for detection of 9 economically significant pepper viruses: CMV, PVY, TSWV, AMV, TMV, PMMoV, Potato virus X (PVX), Pepper mottle virus (PepMoV) and Pepper veinal mottle virus (PVMV) according to the manufacture's manual (Loewe Biochemica, Sauerlach, Germany). Extracts from fresh leaves were ground in extraction buffer in a ratio $1: 10(\mathrm{w} / \mathrm{v})$. After addition of the substrate $(1 \mathrm{mg} / \mathrm{ml}$ of p-nitrophenyl phosphate), the plates were incubated at room temperature for 2 hours and the extinction was measured at $405 \mathrm{~nm}$ (A405) using an ELISA plate reader (Multiscan Ascent, Finland). Samples were considered to be positive when the absorbance values were two times the absorbance values of negative controls. Commercial positive and negative controls (Loewe), as well as healthy pepper leaves were included in each ELISA for validation of the test results.

\section{RT-PCR detection and sequence analysis}

Presence of PVY in four selected pepper samples was further confirmed by conventional reverse transcription (RT)-PCR. Total RNAs were extracted from $100 \mathrm{mg}$ of freeze-dried leaves of naturally infected plants using RNeasy Plant Mini Kit (Qiagen, Hilden, Germany) according to the manufacturer's instructions. RT-PCR was performed using the One-Step RT-PCR Kit (Qiagen) with the PVY specific primer pair PVYc/PVYd (Marie-Jeane Tordo et al., 1995; Glais et al., 1996), yielding a 975-bp fragment corresponding to the partial gene for P1 protein. 
The RT-PCR reaction mixture included $400 \mathrm{Mm}$ each of the four dNTPs, 0.6 $\mu \mathrm{M}$ of the viral sense and complementary sense primer, and $1 \mu 1$ extracted RNA in a final volume of $25 \mu \mathrm{l}$. Amplifications were performed in a thermal cycler (Biometra, T-1 Thermocycler) with the following cycling parameters: reverse transcription at $50^{\circ} \mathrm{C}$ for $30 \mathrm{~min}$ and an initial PCR denaturation step at $95^{\circ} \mathrm{C}$ for $15 \mathrm{~min}$, followed by 35 cycles consisting of a denaturation step of $60 \mathrm{~s}$ at $94^{\circ} \mathrm{C}$, primer annealing for $60 \mathrm{~s}$ at $57^{\circ} \mathrm{C}$, and extension for $60 \mathrm{~s}$ at $72^{\circ} \mathrm{C}$. The final extension was performed at $72^{\circ} \mathrm{C}$ for $10 \mathrm{~min}$. Total RNAs obtained from a Serbian PVY isolate D7-06 from tobacco (GQ290476) and a healthy pepper plant were used as the positive and the negative control, respectively.

The products amplified from the selected isolates were sequenced in both directions, using the same primers directly after purification with a QIAquick PCR Purification Kit (Qiagen). The nucleotide sequences of the amplification products were deposited in GenBank database and they were assigned accession numbers. Sequences of Serbian virus isolates were compared with the previously reported PVY isolates available in the GenBank (http://www.ncbi.nlm.nih.gov/BLAST/) using the ClustalW program (Thompson et al. 1994) and MEGA5 software (Tamura et al., 2011). A p-distance model was applied for nucleotide (nt) and deduced amino acid (aa) sequence analyses and the divergence of selected sequences was calculated using sequences trimmed to the length of the shortest fragment.

\section{Phylogenetic relationship}

The phylogenetic tree was constructed based on the nucleotide sequences of P1 gene of the PVY isolates generated in this study with other PVY (Table 1) isolates from different genotypes and geographic origins available in GenBank databases using maximum parsimony method in MEGA5 software. Genetic diversity within and between groups of host and geographical origin were calculated with Kimura 2-parameter $(\mathrm{K} 2+\mathrm{G})$ which was chosen as the best-fitting model of nt substitution. To assess the statistical significance of the tree, bootstrap values were calculated on 1000 replicates. All branches with bootstrap value support $<50 \%$ were collapsed. The isolate of Pepper mild mottle virus (PMMoV; Acc.No. M96425) was used as the outgroup sequence. 
Table 1. PVY isolates with coat protein sequences from GenBank used in the phylogenetic analysis

\begin{tabular}{llll}
\hline Isolate name* & Country & Host plant & $\begin{array}{l}\text { GenBank } \\
\text { accession number }\end{array}$ \\
\hline D35-06, D7-06 & Serbia & Nicotiana tabacum & GQ290475-76 \\
Slovenia1 & Slovenia & AJ315739 \\
S1 50, Sl 64 & Slovenia & Solanum tuberosum & AF401603-04 \\
PVYN-N242 & French & Solanum tuberosum & AF248499 \\
605 & Switzerland & / & X97895 \\
Tu 648 & Canada & Solanum tuberosum & AF401610 \\
v942490 & United Kingdom & / & EF016294 \\
Linda, Satina & Germany & Nicotiana tabacum & AJ890345, 47 \\
423-3 & USA & Solanum tuberosum & AY884982 \\
N 5Yt & Canada & Nicotiana tabacum & AF401605 \\
Rusia & United Kingdom & $/$ & AJ315746 \\
California & California & / & AJ315744 \\
English & United Kingdom & / Solanum tuberosum & AJ315747 \\
Tu 619, Tu 660 & USA & AF401608-09 \\
N266, N394, N & Canada & Solanum tuberosum & AF401600, 01, 06, \\
27, N Jg & & & 07 \\
Canada & Canada & $/$ & AJ315745 \\
USA & USA & / & AJ315742 \\
Ukraine & Ukraine & / & AJ315740 \\
803, Viikki & Finland & Solanum tuberosum & AJ245555-56 \\
Hungarian & Hungary & $/$ & M95491 \\
Ditta & Poland & Nicotiana tabacum & AJ890344 \\
Scotland & United Kingdom & $/$ & AJ315743 \\
Adgen & French & Solanum tuberosum & AJ890348 \\
LYE84.2 & Spain & Solanum lycopersicum & AJ439545 \\
SON41 & French & Solanum nigrum & AJ439544 \\
& & & \\
& are from GenBank & & \\
& & &
\end{tabular}

\section{Results and Discussion}

\section{Disease incidence and symptomatology in the field}

Disease incidence, as estimated by the number of symptomatic plants in the field, highly varied depending on year and sampling locality, ranging from $20 \%$ to $60 \%$. Pepper plants exhibited a wide range of symptoms, including stunting, shrubby appearance of plants, yellowish and chlorotic patterns (Figure 1a, 1g), leaf deformation (Figure 1c, 1e), mottling (Figure 1d), mild (Figure 1b) or severe mosaic, veinal necrosis, necrotic spots on the leaves (Figure 1h) or necrotic line patterns, as well as stem and branch necrosis. Fruits of infected plants were 
deformed, necrotic (Figure 1f), mottled, or without any symptoms. The observed symptoms were typical of virus infection, as described by many authors (Krstić et al. 1996; Echer and Costa 2002; Ozaslan et al. 2006; Mijatović et al. 2007; Sevik 2011).

Plants can display virus-like symptoms when plants respond to unfavorable weather, nutritional imbalances, infection by other types of pathogens, damage caused by pests or abiotic agents and other factors (van der Want and Dijkstra

2006); therefore the symptoms caused by the viruses have no diagnostic significance.

Figure 1. Symptoms of virus infection on pepper: a) Yellowing (AMV), b) Mosaic (PMMoV), c) Mild mosaic and leaf distortion (CMV), d) Mottling (PVY), e) Mosaic and leaf distortion (CMV+AMV), f) Deformations and necrosis of fruit (PVY+CMV), g) Severe yellowing and leaf distortion (PVY+AMV), h) Necrotic spots (PVY+CMV)

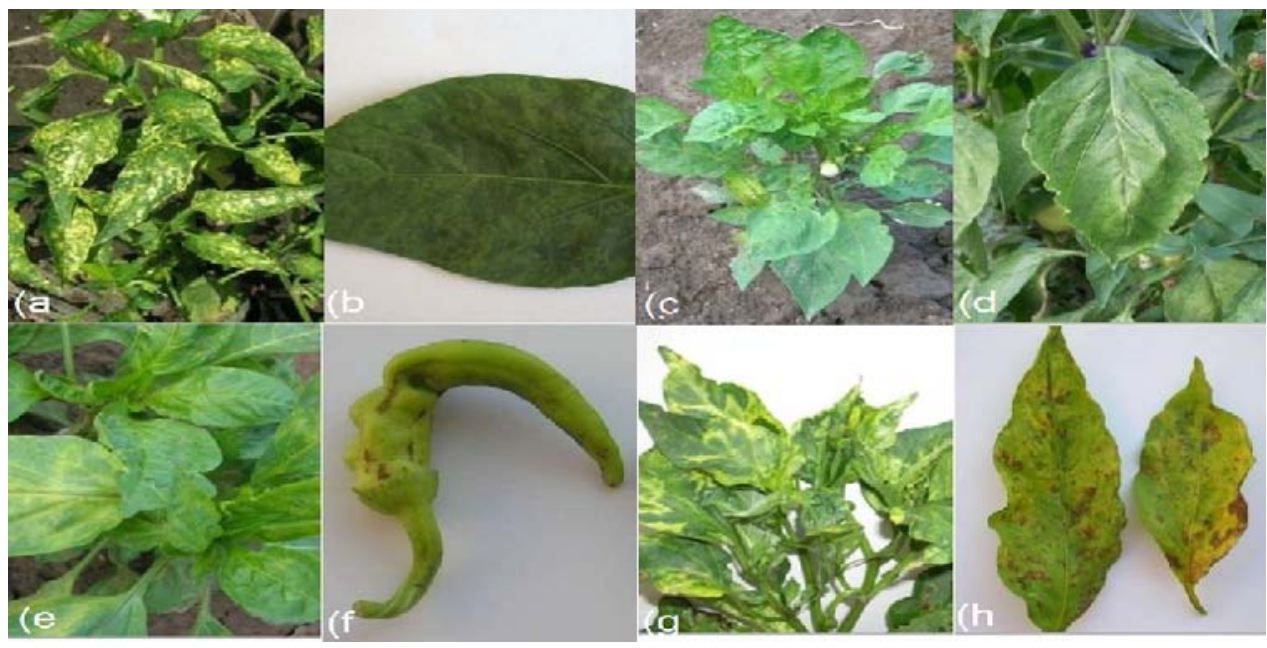

\section{Virus detection and incidence in pepper samples}

Serological analyses of collected pepper samples in 2009 and 2010 detected the presence of four viruses: CMV, PVY, AMV and PMMoV. The relative incidence of detected viruses in collected pepper samples is presented in Table 2.

During 2009, PVY was detected in 14 out of 16 inspected localities and was by far the most prevalent virus both in single (25.6\%) and mixed infections (25.6\%). The second widespread virus was CMV, detected in 13 localities in $37.2 \%$ of analyzed samples. AMV and PMMoV were also detected but at lower percentages. The AMV was detected in $21.7 \%$ of analyzed samples, while PMMoV was detected in only one locality in 3 analyzed samples. The number of 
single infections (56.5\%) was considerably higher than the number of mixed infections (26.6\%). The most frequent type of mixed infections (18.8\%) was infection with two viruses, PVY+CMV (Table 2). Triple infections were found in $1.9 \%$ of the tested samples. In $17 \%$ of the tested samples viruses were not detected.

In 2010, CMV was detected in 12 out of 15 inspected localities and was the most frequent virus both in single (35.4\%) and mixed infections (17.7\%). The second most frequent virus was PVY, detected in 15 localities in $43.0 \%$ of analyzed samples while AMV was detected in $17.7 \%$ of analyzed samples. $\mathrm{PMMoV}$ was detected in only one locality in 2 analyzed samples (1.3\%). Single infections were also the most frequent infection type $(74.7 \%)$, while mixed infection was present in $19.6 \%$ of tested samples. The most frequent type of mixed infections was PVY+CMV (14.6\%), while triple infections were found in $1.3 \%$ (Table 2). None of the tested viruses was observed in $12 \%$ of the samples.

TMV, TSWV, PVX, PepMoV and PVMV were not detected by DAS-ELISA test in any of the tested samples during the two-year period.

In general, PVY was the most frequent virus, identified in $47.7 \%$ of 365 samples collected during the two years of investigation. The second most frequent virus was CMV, which infected $44.1 \%$ of tested samples. AMV was detected in $20 \%$ of tested samples, while the least frequent was PMMoV (1.4\%). Single infections were the most frequent infection type in 2009 and 2010. Most common single infections in total collected samples were those of PVY (25.5\%) and they were prevalent only in 2009, with the lower rate in 2010. A combination of two viruses was the most frequent mixed infection type.

The dominant presence of PVY was confirmed in other areas of pepper production in the world (Fanigliulo et al., 2005; Choi et al., 2005b). Also, PVY was the most frequently found virus in 1998 and the second most frequent in 1999 in Turkey (Arli-Sokmen et al., 2005). As opposed to PVY there are several reports displaying the evidence of the incidence of CMV which infects not only common vegetable crops but also some rare ornamental plants. A significant presence of CMV was demonstrated in other areas of pepper production in the world (Sepulveda et al., 2005; Choi et al., 2005a). According to many authors, CMV and PVY seem to be the most damaging viruses (Fakhfakh et al., 1999; Ben Khalifa et al., 2009). These two viruses often occur in mixed infection, which results in increased severity of the disease through synergy (Syller, 2012), which is in agreement with our studies. This study revealed that PVY and CMV were prevalent viruses in pepper crops in Serbia, but their occurrence, distribution, and relative incidence varied during the investigation. However, the dominant presence of PVY has been observed also in tobacco (Stanković et al., 2011), and it was one of the most frequently found virus in individual and mixed infections in tomato production in Serbia (Nikolić et al., 2018). Furthermore, CMV is well established in the tomato (Nikolić et al., 2018), different pumpkin species (Vučurović et al. 2012), tobacco (Stanković et al., 2011) and other hosts which serve as CMV reservoirs. 
Table 2. Incidence of AMV, CMV, PVY, and PMMoV in single, mixed and total infections in pepper crops in Serbia

\begin{tabular}{|c|c|c|c|c|c|c|c|c|c|c|c|c|c|c|c|c|}
\hline \multirow[b]{2}{*}{ Year } & \multirow[b]{2}{*}{ Locality } & \multirow[b]{2}{*}{ 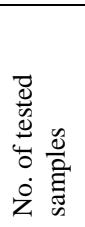 } & \multicolumn{4}{|c|}{ Single infection (\%) } & \multicolumn{6}{|c|}{ Mixed infection (\%) } & \multicolumn{4}{|c|}{ Total infections (\%) } \\
\hline & & & $\frac{3}{2}$ & $\sum_{U}$ & $\sum_{<}$ & $\sum_{0}^{\infty}$ & $\sum_{2} \sum_{+}$ & $\sum_{2} \sum_{+}^{\geq}$ & $\sum_{i} \sum_{+}$ & $\sum_{2}^{2} \sum_{\sum_{+}^{1}}^{0}$ & $\sum_{i} \sum_{+}^{Z} \sum_{+}^{Z}$ & $\sum_{2}^{2} \sum_{\substack{\infty \\
+}}^{0} \sum_{+}^{2}$ & 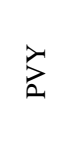 & $\sum_{U}$ & $\sum_{<}$ & $\sum_{i}^{\infty}$ \\
\hline \multirow[t]{16}{*}{2009} & Selenča & 10 & 0 & 0 & 50 & 0 & 0 & 0 & 0 & 0 & 0 & 0 & 0 & 0 & 50 & 0 \\
\hline & Ravno Selo & 15 & 20 & 0 & 33.3 & 0 & 13.3 & 13.3 & 0 & 0 & 6.7 & 0 & 53.3 & 20 & 53.3 & 0 \\
\hline & Đurđevo & 15 & 26.7 & 26.7 & 0 & 0 & 26.7 & 0 & 0 & 0 & 0 & 0 & 53.3 & 53.3 & 0 & 0 \\
\hline & B. Palanka & 15 & 53.3 & 0 & 20 & 0 & 0 & 13.3 & 0 & 0 & 0 & 0 & 66.7 & 0 & 33.3 & 0 \\
\hline & Veternik & 9 & 22.2 & 0 & 0 & 0 & 66.7 & 0 & 0 & 0 & 11.1 & 0 & 100 & 77.8 & 11.1 & 0 \\
\hline & Horgoš I & 10 & 20 & 0 & 60 & 0 & 0 & 0 & 0 & 0 & 0 & 0 & 20 & 0 & 60 & 0 \\
\hline & Horgoš II & 5 & 0 & 20 & 0 & 0 & 60 & 0 & 0 & 0 & 20 & 0 & 80 & 100 & 20 & 0 \\
\hline & Senta & 20 & 35 & 15 & 25 & 0 & 0 & 0 & 0 & 0 & 0 & 0 & 35 & 15 & 25 & 0 \\
\hline & Čonoplja & 9 & 66.7 & 0 & 0 & 0 & 0 & 0 & 0 & 22.2 & 0 & 1 & 100 & 11.1 & 0 & 33.3 \\
\hline & Velika Plana & 15 & 0 & 46.7 & 20 & 0 & 0 & 0 & 13.3 & 0 & 0 & 0 & 0 & 60 & 33.3 & 0 \\
\hline & Smederevo & 15 & 13.3 & 46.7 & 0 & 0 & 40 & 0 & 0 & 0 & 0 & 0 & 53.3 & 86.7 & 0 & 0 \\
\hline & Kraljevo & 15 & 53.3 & 0 & 0 & $0 / 0$ & 26.7 & 0 & 0 & 0 & 0 & 0 & 80 & 26.7 & 0 & 0 \\
\hline & Trstenik & 10 & 40 & 40 & 0 & $0 / 0$ & 0 & 0 & 0 & 0 & 0 & 0 & 40 & 40 & 0 & 0 \\
\hline & Čačak & 15 & 0 & 26.7 & 0 & $0 / 0$ & 40 & 0 & 0 & 0 & 0 & 0 & 40 & 66.7 & 0 & 0 \\
\hline & Inđija & 15 & 33.3 & 0 & 0 & $0 / 0$ & 26.7 & 26.7 & 0 & 0 & 0 & 0 & 86.7 & 26.7 & 26.7 & 0 \\
\hline & Aleksinac & 14 & 14.3 & 14.3 & 35.7 & $0 / 0$ & 28.6 & 0 & 0 & 0 & 0 & 0 & 42.9 & 42.9 & 35.7 & 0 \\
\hline \multicolumn{2}{|l|}{ Subtotal } & 207 & 25.6 & 15.5 & 15.5 & $\mathbf{0}$ & 18.8 & 3.85 & 0.97 & 0.97 & 1.45 & 0.5 & 51.2 & 37.2 & 21.7 & 1.5 \\
\hline
\end{tabular}




\begin{tabular}{|c|c|c|c|c|c|c|c|c|c|c|c|c|c|c|c|c|}
\hline \multirow[b]{2}{*}{ Year } & \multirow[b]{2}{*}{ Locality } & \multirow[b]{2}{*}{ 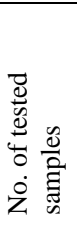 } & \multicolumn{4}{|c|}{ Single infection (\%) } & \multicolumn{6}{|c|}{ Mixed infection (\%) } & \multicolumn{4}{|c|}{ Total infections (\%) } \\
\hline & & & 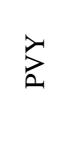 & $\sum_{U}$ & $\sum_{4}$ & $\sum_{i=1}^{>}$ & 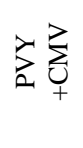 & $\sum_{\Delta} \sum_{+}^{\geq}$ & $\sum_{<} \sum_{+}$ & $\sum_{1}^{2} \sum_{\substack{i \\
+}}^{>}$ & $\sum_{i}^{\gtrless} \sum_{+}^{Z} \sum_{+}^{Z}$ & $\sum_{a}^{\lambda} \sum_{\substack{\infty \\
+}}^{>} \sum_{+}^{0}$ & 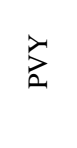 & $\sum_{U}$ & $\sum_{<}$ & $\sum_{i}^{\infty}$ \\
\hline \multirow[t]{15}{*}{2010} & Đurđevo & 7 & 57.1 & 0 & 14.3 & 14.3 & 0 & 0 & 0 & 0 & 0 & 0 & 57.1 & 0 & 14.3 & 14.3 \\
\hline & Bački Jarak & 10 & 20 & 40 & 0 & 0 & 20 & 0 & 10 & 0 & 0 & 0 & 40 & 70 & 10 & 0 \\
\hline & Bukovac & 10 & 50 & 10 & 0 & 0 & 30 & 0 & 0 & 0 & 0 & 0 & 80 & 40 & 0 & 0 \\
\hline & Rimski Šančevi & 10 & 20 & 30 & 20 & 0 & 20 & 0 & 10 & 0 & 0 & 0 & 40 & 60 & 30 & 0 \\
\hline & Bačka Topola & 15 & 0 & 40 & 26.7 & 0 & 20 & 0 & 0 & 0 & 0 & 0 & 20 & 60 & 26.7 & 0 \\
\hline & Ruma & 15 & 13.3 & 60 & 0 & 0 & 0 & 0 & 0 & 0 & 0 & 0 & 13.3 & 60 & 0 & 0 \\
\hline & Vašica & 7 & 14.3 & 14.3 & 14.3 & 0 & 51.1 & 0 & 0 & 0 & 0 & 0 & 71.4 & 71.4 & 14.3 & 0 \\
\hline & Šabac & 10 & 40 & 0 & 20 & 0 & 10 & 10 & 0 & 0 & 0 & 0 & 60 & 10 & 30 & 0 \\
\hline & Horgoš & 15 & 13.3 & 53.3 & 6.7 & 0 & 20 & 0 & 0 & 0 & 6.7 & 0 & 40 & 80 & 13.3 & 0 \\
\hline & Kikinda & 7 & 14.3 & 71.4 & 0 & 0 & 0 & 0 & 0 & 0 & 0 & 0 & 14,3 & 71.4 & 0 & 0 \\
\hline & Čonopla & 15 & 46.7 & 71.4 & 0 & 0 & 13.3 & 0 & 0 & 0 & 0 & 6.7 & 66.7 & 53.3 & 0 & 6.7 \\
\hline & Smederevo & 5 & 100 & 0 & 0 & 0 & 0 & 0 & 0 & 0 & 0 & 0 & 100 & 0 & 0 & 0 \\
\hline & Užice & 10 & 0 & 0 & 30 & 0 & 0 & 20 & 0 & 0 & 0 & 0 & 20 & 0 & 50 & 0 \\
\hline & Aleksinac & 12 & 16.7 & 58.3 & 8.3 & 0 & 0 & 0 & 8.3 & 0 & 0 & 0 & 16.7 & 66.7 & 16.7 & 0 \\
\hline & Valjevo & 10 & 20 & 30 & 20 & 0 & 10 & 0 & 0 & 0 & 0 & 0 & 40 & 40 & 20 & 0 \\
\hline \multicolumn{2}{|l|}{ Subtotal } & 158 & 25.3 & 35.4 & 13.3 & 0.6 & 14.6 & 1.9 & 1.9 & $\mathbf{0}$ & 0.6 & 0.6 & 43.0 & 53.2 & 17.7 & 1.3 \\
\hline \multicolumn{2}{|l|}{ Total } & 365 & 25.5 & 24.1 & 14.5 & 0.3 & 17.0 & 3.0 & 1.4 & 0.6 & 1.1 & 2.0 & 47.7 & 44.1 & 20 & 1.4 \\
\hline
\end{tabular}


Difficulties in controlling PVY and CMV infections are caused by the great variability of the virus, their polyphagous nature and numerous aphid vectors which transmit the virus with different efficiencies.

\section{Molecular detection and sequence identity analyses of PVY isolates}

Specific primers (PVYc/PVYd) for the detection of PVY were able to amplify target cDNA fragments of predicted size and successfully detect the presence of the virus in all selected ELISA-positive samples. No amplification product was observed in the healthy pepper control. After purification, the identities of obtained amplicons were confirmed by sequencing.

The nucleotide sequences of the fragment of the P1 gene derived from the isolates PL-3-10 (KC288144), PL-28-09 (KC288142), PL-15-09 (KC288143) and PL-108-10 (KC288144) shared nucleotide identity from 99.1 to $99.9 \%$ (100 $\%$ aa identity). Isolates PL-3-10 exhibited the highest nucleotide identity (99.2\%) with Slovenian isolate (AF401604), Croatian isolate (JF927749), German isolate (JF927756) and tobacco isolate (GQ290476) from Serbia. PL-15-09, PL-28-09 and PL-108-10 also exhibited the highest nucleotide identity (100\%, 100\% and $99.8 \%$, respectively) with the above isolates.

The phylogenetic tree constructed using the maximum parsimony method based on sequences of the P1 gene of PVY showed the separation of selected isolates into three consistent lineages as reported earlier: N, C, and O (Moury et al., 2002; Fanigliulo et al., 2005; Glais et al., 2002, 2005; Lorenzen et al., 2006; Ogawa et al., 2008, 2012). N lineage was split into two sublineages (N-1 and N2, previously described as N-Europe and N-North America sublineages, respectively), as reported in an earlier study by Ogawa et al. (2008). Genetic diversity among three molecular groups of isolates ranged from $0.087 \pm 0.010$ to $0.374 \pm 0.026$, whereas within each group the range was: $0.010 \pm 0.002(\mathrm{~N}-1)$, $0.019 \pm 0.003(\mathrm{~N}-2), 0.141 \pm 0.011$ (C) and $0.046 \pm 0.005(\mathrm{O})$. All of the four Serbian isolates were clustered in sublineage N-1 with other European isolates of necrotic strains. The lowest genetic diversity was between sublineages $(0.087 \pm 0.010)$, while the highest genetic diversity $(0.374 \pm 0.026)$ was between sublineages $\mathrm{N}-1$ and lineages $\mathrm{C}$, and sublineages $\mathrm{N}-2$ and lineages C. Some exceptions were observed, such as placing of some isolates from Canada and the USA in the group of European necrotic isolates, thus confirming their European origin and probable introduction through potato import. The opposite situation was also observed, such as placing of isolates from Great Britain in the group with North American necrotic isolates, which confirms the "gene flow" between Europe and North America, enabled by the intensive exchange of plant material (Đekić, 2010).

Analysis of P1 gene sequences of four selected PVY isolates did not determine the heterogencity of this virus population which originated from pepper in Serbia. All tested PVY isolates originating from pepper were grouped 
into subcluster of necrotic isolates from Europe, as were the previously characterized PVY isolates from Serbia originating from tobacco (Đekić et al., 2007). However, recent research has indicated that recombinations occur not only between strains, but also between different phylogenetic groups of the same strain, as well as between recombinants (Schubert et al., 2007; Chikh Ali et al., 2010; Kerlan et al., 2011). Therefore, further examination of pepper PVY isolates from Serbia should be focused on sequencing of the whole genome to obtain a clear overview of variability and composition of the virus population in Serbia, as well as an insight into the main sources which spread PVY infection to susceptible crops.

Figure 2. Maximum parsimony tree based on nucleotide sequences of partial gene of P1 protein of KC288144, KC288142, KC288145 and KC288143 isolates of Potato virus $Y$ (PVY) using M96425 isolate as out-group sequence. The four Serbian isolates are underlined

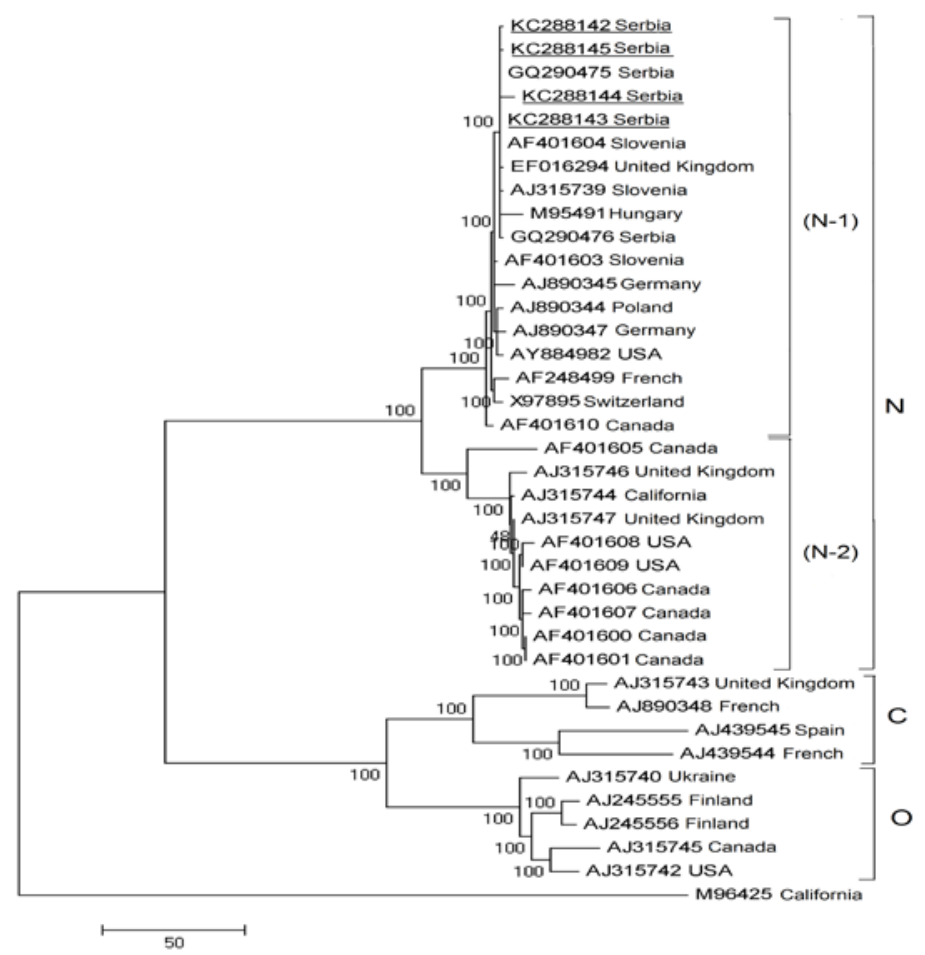




\section{Conclusions}

There is a need to develop resistant pepper varieties to overcome this disease threat. Knowledge of the pathogen and its variants or strains is a vital prerequisite for reliable breeding for resistance. This investigation provides essential basic information useful for pepper virus control in Serbia. An important option for virus disease control would be to enhance growers' acquaintance with control measures against pepper viruses and their vectors, especially those directed to limit early virus infections. The information about phylogenetic and genetic diversity obtained in this study will provide the first insight into the genetic structure of PVY isolates from pepper in Serbia.

\section{Acknowledgements}

This research was supported by grants TR31030 and III-43001 of the Ministry of Education, Science and Technological Development of the Republic of Serbia.

\section{References}

Ali M.C., Maoka T., Natsuaki K.T. (2007): The occurrence and characterization of new recombinant isolates of PVY displaying shared properties of $\mathrm{PVY}^{\mathrm{NW}}$ and $\mathrm{PVY}^{\mathrm{NTN}}$. J. Phytopathology, 155: 409-415.

Ali M.C., Maokac T., Natsuakid K.T., Natsuakia T. (2010): The simultaneous differentiation of Potato virus $\mathrm{Y}$ strains including the newly described strain PVY $^{\mathrm{NTN} \_N W}$ by multiplex PCR assay. Journal of Virological Methods, 165: 15-20.

Arli-Sokmen M., Mennan H., Sevik M.A., Ecevit O. (2005): Occurrence of viruses in field-grown pepper crops and some of their reservoir weed hosts in Samsun, Turkey. Phytoparasitica, 33 (4): 347-358.

Ben Khalifa M., Simon V., Marrackchi M., Fakhfakh H., Moury B. (2009): Contribution of host plant resistance and geographic distance to the structure of Potato virus $Y$ (PVY) populations in pepper in northern Tunisia. Plant Pathology, 58: 763-72.

Chikh-Ali M., Gray S.M., Karasev A.V. (2013): An Improved Multiplex IC-RT-PCR Assay Distinguishes Nine Strains of Potato virus Y. Plant Disease, 97: 1370-1374.

Choi G. S., Kim J. H., Lee D. H., Kim J. S., Ryu K. H. (2005a): Occurrence and Distribution of Viruses Infecting Pepper in Korea. Journal of Plant Pathology, 21 (3): 258-261.

Choi H. S., Ko S. J., Kim M. K., Park J. W., Lee S. H., Kim K. H., Were H. K., Choi J. K., Takanami Y. (2005b): Characteristics of Potato virus Y Isolated from Paprika in Korea. Journal of Plant Pathology, 21 (4): 349-354.

Đekić I. (2010): Priusutvo,asprostranjenost i karakterizacija virusa duvana u Srbiji. Doktorska disertacija. Poljoprivredni fakultetu Univerziteta u Beogradu.

Đekić I., Bulajić A., Zindović J., Berenji J., Pauković M., Krstić B. (2007): Identifikacija sojeva virusa crtičastog mozaika krompira na duvanu. Pesticidi i fitomedicina, 22: 155-163. 
Echer M. de M., Costa C. de P. (2002): Reaction of sweet pepper to the potato virus Y $\left(\mathrm{PVY}^{\mathrm{m}}\right)^{1}$. Scientia Agricola, 59 (2): 309-314.

Fakhfakh H., Gorsane F., Marrakchi M., Makni M. (1999): Differentiation of Tunisian isolates of Cucumber mosaic virus using biological and molecular properties. Phytopathologia Mediterranea, 38: 61-7.

Fanigliulo A., Comes S., Pacella R., Harrach B., Martin D. P., Crescenzi A. (2005): Characterization of Potato virus $\mathrm{Y}^{\mathrm{nnp}}$ strain inducing veinal nebrosis in pepper: a naturally occurring recombinant strain of PVY. Archives of Virology, 150: 709-720.

Glais L., Kerlan C., Tribodet M., Marie-Jeanne Tordo V., Robaglia C., Astier-Manifacier S. (1996): Molecular characterization of Potato virus YN isolates by PCR-RFLP. European Journal of Plant Pathology, 102: 655-662.

Glais L., Tribodet M., Kerlan C. (2002): Genomic variability in Potato virus Y: evidence that PVYNW and PVYNTN variants are single to multiple recombinants between PVYO and PVYNTN isolates. Archives of Virology, 147, 363-378.

Glais L., Tribodet M., Kerlan C. (2005): Specific detection of the PVYN-W variant of Potato virus Y. Journal of Virological Methods, 125: 131-136.

Hull R., Davies J.W. (1992): Approaches to non-conventional control of plant virus diseases. Critical Reviews in Plant Sciences, 11: 17-33.

Jones J.B, Thomas A.Z., Timur M.M., Miller S.A. (2014): Compendium of Tomato Diseases and Pests. APS Press, St. Paul, Minnesota, USA.

Katis N., Gibson R. W. (1985): Transmission of potato virus Y by cereal aphids. Potato Res. 28 (1): 65-75.

Krstić B., Krnjaja V., Mijatović M., Tošić M. (1996): Virus blagog šarenila paprike prisutan u Srbiji. Zbornik kratkih sadržaja Prvog balkanskog simpozijuma Povrće i krompir: 164.

Krstić B., Bulajić A. (2008): Ekonomski značajni i karantinski virusi paprike u Srbiji. Zbornik radova IX Savetovanja "Savremena proizvodnja povrća“, Novi Sad: 24-28.

Lorenzen J. H., Meacham T., Berger P. H., Shiel P. J., Crosslin J. M., Hamm P. B., Kopp H. (2006): Whole genome characterization of Potato virus $\mathrm{Y}$ isolates collected in the western USA and their comparison to isolates from Europe and Canada. Archives of Virology, 151 (6): 1055-1074.

Marie-Jeanne Tordo V., Chschulska A. M., Fakhfakh H., Le Romancer M., Robaglia C., Astier-Manifacier S. (1995): Sequence polymorphism in the 5' NTR and in the P1 codng region of Potato virus Y genomic RNA. Journal of General Virology, 76: 939949.

Mijatović M., Obradović A., Ivanović M. (2007): Zaštita povrća. AgroMivas, Smederevska Palanka.

Moury B., Verdin E. (2012): Advances in Virus Research: Viruses of Pepper Crops in the Mediterranean Basin: A Remarkable Stasis, Volume 84: 127-162.

Moury B., Morel C., Johansen E., Jacquemond M. (2002): Evidence for diversifying selection in Potato virus $\mathrm{Y}$ and in the coat protein of other potyviruses. Journal of General Virology, 83: 2563-2573.

Nikolić D., Vučurović A., Stanković I., Radović N., Zečević K., Bulajić A., Krstić B. (2018): Viruses affecting tomato crops in Serbia. European Journal of Plant Pathology.

Nono-Womdim R. (2001): An Africa over view of major disease of vegetable crops in Africa and some aspect of their control, Plant virology in sub Sahara: 213-230. 
Ogawa T., Nakagawa A., Hataya T., Ohshima K. (2012): The Genetic Structure of Populations of Potato virus Y in Japan; Based on the Analysis of 20 Full Genomic Sequences. Journal of Phytopathology, 160: 661-673.

Ogawa T., Tomitaka Y., Nakagawa A., Ohshima K. (2008): Genetic structure of a population of Potato virus $\mathrm{Y}$ inducing potato tuber necrotic ringspot disease in Japan; comparison with North American and European populations. Virus Research, 131: 199-212.

Ozaslan M., Bas B., Aytekin, T., Sigırc1, Z. (2006): Identification of pepper viruses by DAS-ELISA assays in gaziantep-Turkey. Journal of Plant Pathology, 5: 11-14.

Pernezny K. L., Roberts P. D., Murphy J. F., Goldberg N.P. (2003): Compendium of pepper diseases. The American Phytopathological Society, St. Paul, Minnesota, USA.

Petrović D., Bulajić A., Stanković I., Ignjatov M., Vujaković M., Krstić B. (2010): Prisustvo i rasprostranjenost virusa paprike u Srbiji. Ratarstvo i povrtarstvo, 47 (2): 567-576.

Schubert J., Fomitcheva V., Sztangret-Wisniewska J. (2007): Differentiation of Potato virus $\mathrm{Y}$ strains using improved sets of diagnostic PCR-promers. Journal of Virological Methods, 140: 66-74.

Sepulveda P., Larrain P., Quiroz C., Rebufel P., Grana F. (2005): Identification and incidence of pepper viruses in north central Chile and its association with vectors. Agricultura Tecnica, 65: 235-245.

Sevik M.A. (2011): Occurrence of pepper mild mottle virus in greenhouse grown pepper (Capsicum annuum L.) in the West Mediterranean region of Turkey. African Journal of Biotechnology, 10 (25): 4976-4979.

Stanković I., Bulajić A., Vučurović A., Ristić D., Milojević K., Berenji J., Krstić B. (2011): Status of tobacco viruses in Serbia and molecular characterization of Tomato spotted wilt virus isolates. Acta Virologica, 55: 337-347.

Syller J. (2012): Facilitative and antagonistic interactions between plant viruses in mixed infections. Molecular Plant Pathology, 13: 204-16.

Tamura K., Peterson D., Peterson N., Stecher G., Nei M., Kumar S. (2011): MEGA5: Molecular evolutionary genetics analysis using maximum likelihood, evolutionary distance, and maximum parsimony methods. Molecular Biology and Evolution, 28: 2731-2739.

Thompson J.D., Higgins D.G., Gibson T.J. (1994): CLUSTAL W: Improving the sensitivity of progressive multiple sequence alignment through sequence weighting, position-specific gap penalties and weight matrix choice. Nucleic Acids Research, 22: 4673-4680.

van der Want J. P. H., Dijkstra J. (2006): A history of plant virology. Archives of Virology, 151: 1467-1498

Van Fanbing L. (1999): Monoclonal and recombinant antibodies of potyviral proteins and their application. Ph. D. Thesis, Stuttgart University, Germany.

Vučurović A., Bulajić A., Stanković I., Ristić D., Berenji J., Jović J., Krstić B. (2012): Non-persistently aphid-borne viruses infecting pumpkin and squash in Serbia and partial characterization of Zucchini yellow mosaic virus isolates. European Journal of Plant Pathology, 133: 935-947.

Woodford J.A.T. (1992): Virus transmission by aphids in potato crops. Netherlands Journal of Plant Pathology, 98 (2): 47-54. 
Acta Agriculturae Serbica, Vol. XXIII, 46(2018); 141-155

\title{
PRISUSTVO I RASPROSTRANJENOST VIRUSA PAPRIKE U SRBIJI
}

\author{
Dragana Milošević ${ }^{\text {, Maja Ignjatov }}{ }^{1}$, Ivana Stanković ${ }^{2}$, \\ Zorica Nikolić ${ }^{1}$, Jelica Gvozdanović-Varga ${ }^{1}$, Branka Krstić \\ ${ }^{1}$ Institut za ratarstvo i povrtarstvo, Novi Sad \\ ${ }^{2}$ Univerzitet u Beogradu-Poljoprivredni fakultet, Beograd
}

\section{Rezime}

Dvogodišnjim poučavanjima (2009-2010) prisustva i rasprostranjenosti virusa u usevu paprike u Srbiji utvrđeno je da se virusi javljaju svake godine $u$ proizvodnji paprike na otvorenom polju. Intenzitet zaraze bio je različit i kretao se od $20 \%$ do $60 \%$, u zavisnosti od ispitivane godine i lokaliteta gajenja paprike. Serološkim testiranjem uzoraka paprike prikupljenih u više lokaliteta u Srbiji, tokom 2009 i 2010. godine detektovani su Cucumber mosaic virus (CMV), Potato virus Y (PVY), Alfalfa mosaic virus (AMV) and Pepper mild mottle virus (PMMoV), pri čemu je PVY bio dominantan. Specifičnim prajmerima PVYc/PVYd uz upotrebu RT-PCR metode umnožen je deo genoma od oko 975 bp koji kodira P1 protein. Amplifikovani fragmenti su sekvencirani i prijavljeni u GenBank bazu podataka, gde su im dodeljeni pristupni brojevi PL-28-09 (KC288142), PL-15-09 (KC288143), PL-3-10 (KC288144), PL-108-10 (KC288144). Proračunom genetičke sličnosti sekvenci izolata dobijenih u ovom radu utvrđen je visok stepen nukleotidne sličnosti, koji se kretao od 99,8-100\%. Ispitivane sekvence PVY izolata iz Srbije dele najveću nukleotidnu i aminokiselinsku sličnost sa izolatima iz Slovenije, Hrvatske, Nemačke i izolatom duvana iz Srbije. Svi ispitivani izolati sa paprike poreklom iz Srbije grupisani su u subklaster nekrotičnih izolata poreklom iz Evrope.

Ključne reči: virusi paprike, serološka analiza, RT-PCR test, molekularna karakterizacija. 